Prepared in cooperation with the city of Rapid City

\title{
Algal and Water-Quality Data for Rapid Creek and Canyon Lake near Rapid City, South Dakota, 2007
}

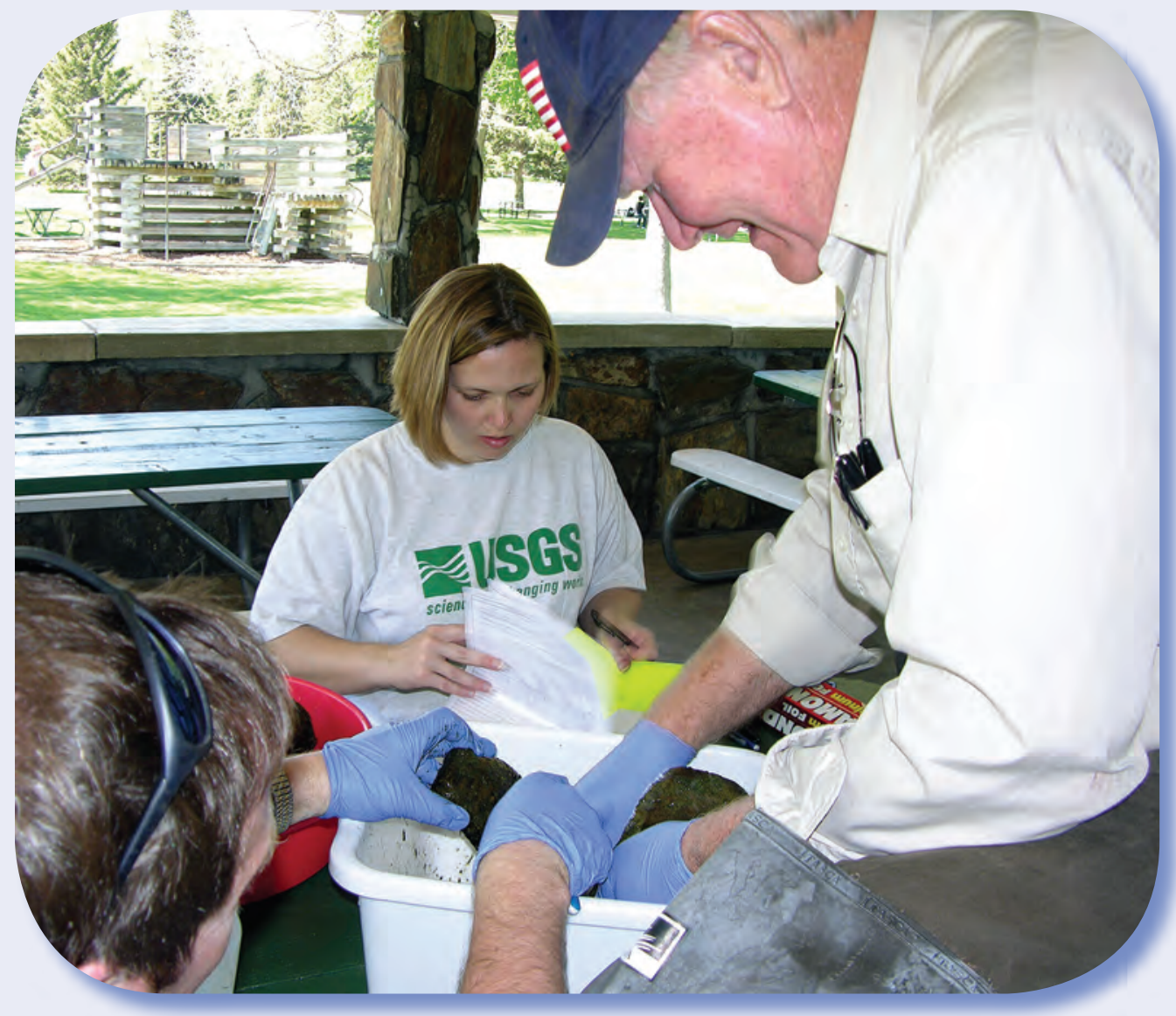

Data Series 354 
Cover photograph: U.S. Geological Survey hydrologists preparing periphyton algae samples from rocks collected in Rapid Creek. Photograph by Mark T. Anderson. 


\section{Algal and Water-Quality Data for Rapid Creek and Canyon Lake near Rapid City, South Dakota, 2007}

By Galen K. Hoogestraat, Larry D. Putnam, and Jennifer L. Graham

Prepared in cooperation with the city of Rapid City

Data Series 354 


\section{U.S. Department of the Interior DIRK KEMPTHORNE, Secretary}

\section{U.S. Geological Survey \\ Mark D. Myers, Director}

\section{U.S. Geological Survey, Reston, Virginia: 2008}

For product and ordering information:

World Wide Web: http://www.usgs.gov/pubprod

Telephone: 1-888-ASK-USGS

For more information on the USGS — the Federal source for science about the Earth, its natural and living resources, natural hazards, and the environment:

World Wide Web: http://www.usgs.gov

Telephone: 1-888-ASK-USGS

Any use of trade, product, or firm names is for descriptive purposes only and does not imply endorsement by the U.S. Government.

Although this report is in the public domain, permission must be secured from the individual copyright owners to reproduce any copyrighted materials contained within this report.

Suggested citation:

Hoogestraat, G.K., Putnam, L.D., and Graham, J.L., 2008, Algal and water-quality data for Rapid Creek and Canyon Lake near Rapid City, South Dakota, 2007: U.S. Geological Survey Data Series 354, 16 p. 


\section{Contents}

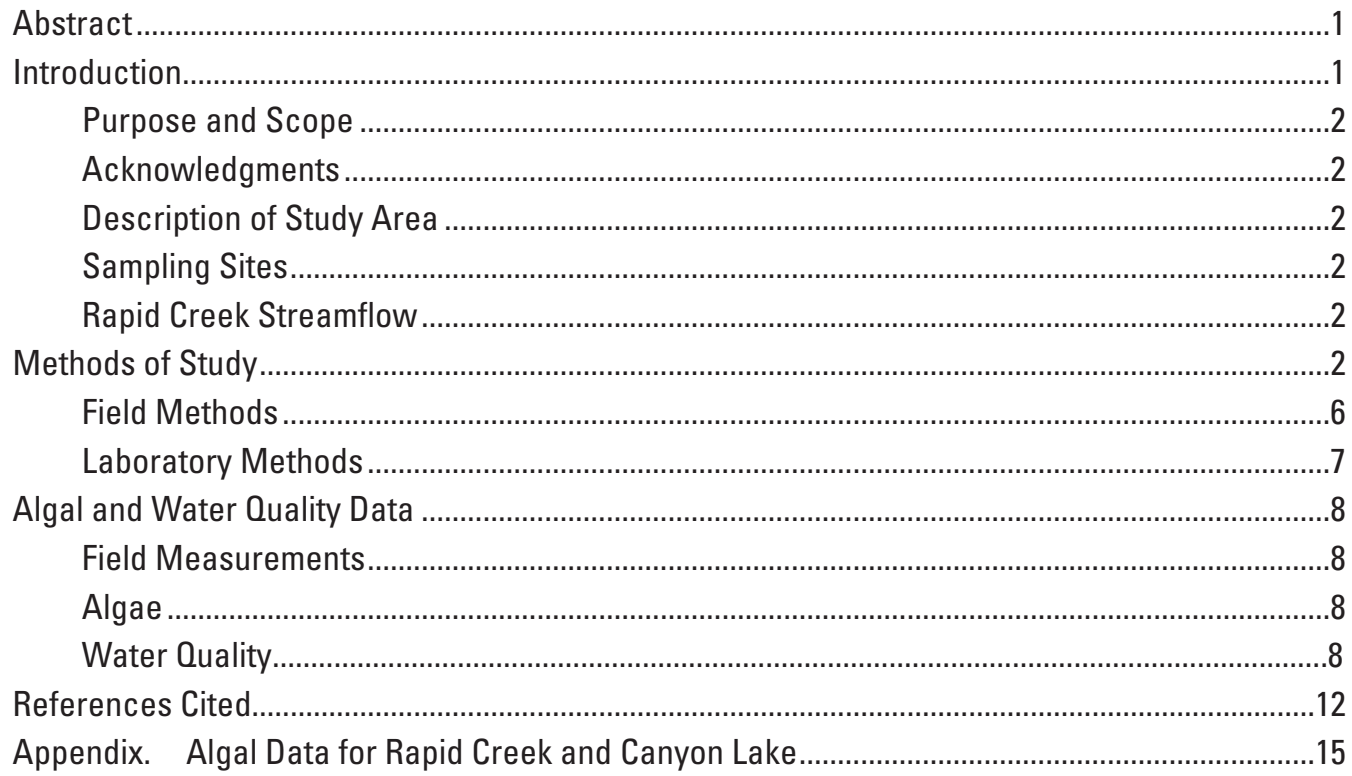

\section{Figures}

1-2. Maps showing:

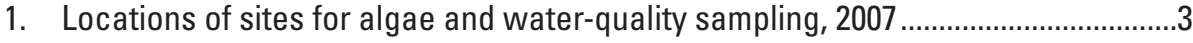

2. Locations of sites for algae and water-quality sampling near Canyon Lake, 2007

3. Graph showing daily mean streamflow for station 06412500 for water year 2007

\section{Tables}

1. Depth profile of field water-quality measurements at Canyon Lake (site 11), May 8, 2007 . .4

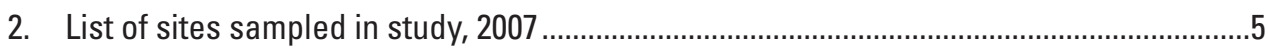

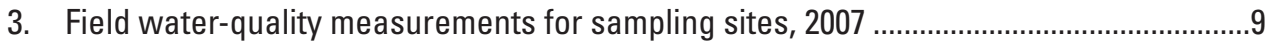

4. Relative abundance of algal divisions (percent of total biovolume) in phytoplankton samples collected during May 2007

5. Relative abundance of algal divisions (percent of total biovolume) in quantitative periphyton samples collected during May 2007.

6. Relative abundance of algal divisions (percent of total biovolume) in quantitative periphyton samples collected during September 2007.

7. Water-quality data for samples analyzed for geosmin, 2-methylisoborneol (MIB), and actinomycetes, 2007

8. List of spreadsheets and their links that contain algal data 


\section{Conversion Factors}

\begin{tabular}{lll}
\hline Multiply & By & To obtain \\
\hline foot $(\mathrm{ft})$ & 0.3048 & meter $(\mathrm{m})$ \\
mile $(\mathrm{mi})$ & 1.609 & kilometer $(\mathrm{km})$ \\
acre & 0.004047 & square kilometer $\left(\mathrm{km}^{2}\right)$ \\
square mile $\left(\mathrm{mi}^{2}\right)$ & 2.590 & square kilometer $\left(\mathrm{km}^{2}\right)$ \\
liter $(\mathrm{L})$ & 0.2581 & gallon $(\mathrm{gal})$ \\
cubic yard $\left(\mathrm{yd}^{3}\right)$ & 0.7646 & cubic meter $\left(\mathrm{m}^{3}\right)$ \\
square centimeter $\left(\mathrm{cm}^{2}\right)$ & 0.1550 & square inch $\left(\mathrm{in}^{2}\right)$ \\
cubic foot per second $\left(\mathrm{ft}^{3} / \mathrm{s}\right)$ & 0.02832 & cubic meter per second $\left(\mathrm{m}^{3} / \mathrm{s}\right)$ \\
\hline
\end{tabular}

Temperature in degrees Celsius $\left({ }^{\circ} \mathrm{C}\right)$ may be converted to degrees Fahrenheit $\left({ }^{\circ} \mathrm{F}\right)$ as follows:

$$
{ }^{\circ} \mathrm{F}=\left(1.8 x^{\circ} \mathrm{C}\right)+32
$$

Horizontal coordinate information is referenced to the North American Datum of 1927 (NAD 27).

Vertical coordinate information is referenced to the National Geodetic Vertical Datum of 1929 (NGVD29).

Altitude, as used in this report, refers to distance above the vertical datum.

Specific conductance is given in microsiemens per centimeter at 25 degrees Celsius $(\mu \mathrm{S} / \mathrm{cm}$ at $\left.25^{\circ} \mathrm{C}\right)$.

Concentrations of chemical constituents in water are given either in milligrams per liter (mg/L) or micrograms per liter ( $\mu \mathrm{g} / \mathrm{L})$.

Concentrations of biological constituents in water are given in colonies per milliliter (col/mL) or cells per liter (cells/L).

Algal biovolumes for phytoplankton and periphyton are given in cubic micrometers per milliliter of sample volume $\left(\mu \mathrm{m}^{3} / \mathrm{mL}\right)$ or cubic micrometers per square centimeter of collection area $\left(\mu \mathrm{m}^{3} / \mathrm{cm}^{2}\right)$, respectively.

Algal cell densities for phytoplankton and periphyton are given in cells per milliliter of sample (cells $/ \mathrm{mL}$ ) and cells per square centimeter of collection area (cells $/ \mathrm{cm}^{2}$ ), respectively.

Water year (WY) is the 12-month period, October 1 through September 30, and is designated by the calendar year in which it ends. Thus, the water year ending September 30, 2007, is called "water year 2007." 


\title{
Abbreviations and Acronyms
}

\author{
CL Canyon Lake \\ DENR Department of Environment and Natural Resources \\ HDPE high-density polyethylene \\ MIB 2-methylisoborneol \\ USGS U.S. Geological Survey \\ WTP water treatment plant \\ WY water year \\ $\mathrm{BOD}_{5} \quad$ 5-day biochemical oxygen demand
}





\title{
Algal and Water-Quality Data for Rapid Creek and Canyon Lake near Rapid City, South Dakota, 2007
}

\author{
By Galen K. Hoogestraat, Larry D. Putnam, and Jennifer L. Graham
}

\section{Abstract}

This report summarizes the results of algae and waterquality sampling on Rapid Creek and Canyon Lake during May and September 2007. The overall purpose of the study was to determine the algal community composition of Rapid Creek and Canyon Lake in relation to organisms that are known producers of unwanted tastes and odors in drinkingwater supplies. Algal assemblage structure (phytoplankton and periphyton) was examined at 16 sites on Rapid Creek and Canyon Lake during May and September 2007, and actinomycetes bacteria were sampled at the Rapid City water treatment plant intake in May 2007, to determine if tasteand-odor producing organisms were present. During the May 2007 sampling, 3 Rapid Creek sites and 4 Canyon Lake sites were quantitatively sampled for phytoplankton in the water column, 7 Rapid Creek sites were quantitatively sampled for attached periphyton, and 4 lake and retention pond sites were qualitatively sampled for periphyton. Five Rapid Creek sites were sampled for geosmin and 2-methylisoborneol, two common taste-and-odor causing compounds known to affect water supplies. During the September 2007 sampling, 4 Rapid Creek sites were quantitatively sampled for attached periphyton, and 3 Canyon Lake sites were qualitatively sampled for periphyton. Water temperature, dissolved oxygen, $\mathrm{pH}$, and specific conductance were measured during each sampling event. Methods of collection and sample analysis are presented for the various types of biological and chemical constituent samples.

Diatoms comprised 91-100 percent of the total algal biovolume in periphyton samples collected during May and September. Cyanobacteria (also called blue-green algae) were detected in 7 of the 11 quantitative periphyton samples and ranged from 0.01 to 2.0 percent of the total biovolume. Cyanobacteria were present in 3 of the 7 phytoplankton samples collected in May, but the relative biovolumes were small (0.01-0.2 percent). Six of seven qualitative samples collected from Canyon Lake and retention ponds during May and September also contained cyanobacteria. Geosmin and 2-methylisoborneol concentrations were less than detection limits $(0.005 \mu \mathrm{g} / \mathrm{L})$ in all five of the Rapid Creek samples collected in May. Actinomycetes bacteria were present at the water treatment plant intake in May 2007, at a concentration of 6 colonies per milliliter. During this study, no taste-andodor problems with the drinking water within the study area were reported. However, the presence of cyanobacterial taxa known to contain taste-and-odor producing strains (such as Leptolyngbya, Phormidium, and Anabaena) indicates the potential for taste-and-odor problems under certain physical and chemical conditions.

\section{Introduction}

The reach of Rapid Creek from below Pactola Reservoir downstream to the Rapid City water treatment plant (WTP) intake is an important resource for recreation and is a seasonal source of drinking water for Rapid City. Canyon Lake, an impoundment on Rapid Creek near the west boundary of Rapid City, provides residents with areas for fishing, boating, and other recreation. Rapid City uses Rapid Creek water to supplement its drinking-water supply through the WTP intake downstream from Canyon Lake. In the spring of 1987, residents began to report tastes and odors in their drinking water. Results of a 1989 report by the South Dakota Department of Water and Natural Resources (now known as the Department of Environment and Natural Resources, DENR) concluded that Canyon Lake was acting as a nutrient and sediment sink that probably stimulated an increase in aquatic plant growth within the lake (Allen Heakin, U.S. Geological Survey, written commun., 1999). Other organisms thought to contribute to poor tastes and odors included cyanobacteria (organisms from the algal division Cyanophyta, or "blue-green algae") and actinomycetes bacteria, both of which produce the taste-and-odor compounds geosmin and 2-methylisoborneol (MIB; Mallevialle and Suffet, 1987).

The U.S. Geological Survey (USGS), in cooperation with the city of Rapid City, conducted a reconnaissance study in 2007 to characterize the presence of taste-andodor causing organisms. The study objective was to determine the algal community composition of Rapid Creek and Canyon Lake with respect to organisms that are known producers of unwanted tastes and odors in drinking water supplies. Of particular interest for human-health concerns are the cyanobacteria, which have been shown to produce geosmin and MIB and also have been linked to production of 
dermatoxins that may cause skin irritation, hepatoxins (notably microcystin) that may cause liver damage, and neurotoxins that can affect nervous system function or cause tissue damage (Graham and others, 2008).

\section{Purpose and Scope}

The purpose of this data report is to document the waterquality, algae, and actinomycetes data collected during May and September 2007. Samples were collected at 16 sites on Rapid Creek and Canyon Lake in the reach from Pactola Dam to the WTP intake. Data presented in this report include sample results in the following groups: quantitative phytoplankton, quantitative periphyton, qualitative periphyton, water-quality compounds related to taste-and-odor problems (geosmin and MIB), actinomycetes bacteria, and field waterquality measurements (water temperature, dissolved oxygen, specific conductance, and $\mathrm{pH}$ ).

\section{Acknowledgments}

The authors extend thanks to Roy Bartholomay and Barbara Rowe, U.S. Geological Survey, for their assistance in the field work. The South Dakota Department of Game, Fish, and Parks provided equipment and support for field sampling.

\section{Description of Study Area}

The study area includes the 26-mile (mi) reach of Rapid Creek from Pactola Dam to the Rapid City WTP, which is about 2.4 mi downstream from Canyon Lake (fig. 1). The drainage area above USGS gaging station 06412500 on Rapid Creek at the west city limits of Rapid City (fig. 1) is 371 square miles $\left(\mathrm{mi}^{2}\right)$, and the mean annual streamflow for water years 1964-2007 was 50.8 cubic feet per second $\left(\mathrm{ft}^{3} / \mathrm{s}\right)$. The altitude of the stream ranges from 4,406 feet (ft) at gaging station 06411500 (below Pactola Dam) to about 3,265 ft at gaging station 06413720 (at the WTP). Several water-quality investigations (Driscoll and others, 2000; Williamson and Carter, 2001) in the Black Hills area of South Dakota have included data from several sites in the Rapid Creek watershed. Figure 1 shows the locations where water-quality, algae, and actinomycetes samples were collected in 2007 for the current study.

Canyon Lake is a small (29 acres), shallow (maximum depth $=10$ feet) reservoir on Rapid Creek just inside the west boundary of Rapid City. Canyon Lake was completely drained following a breach of the dam during a flood in 1972, but the dam was subsequently rebuilt and the lake refilled. A restoration project completed in the mid-1990s drained the lake and removed an estimated 47,000 cubic yards of sediment to restore the lake contours more closely to those established when the lake was rebuilt following the 1972 flood. Also included in the project were the removal of aquatic plants from the lake bottom and the installation of a rock jetty (fig. 2) to divert flow around the island and increase water residence time (Allen Heakin, U.S. Geological Survey, written commun., 1999). Figure 2 shows the locations of sites sampled in and around Canyon Lake.

The depth of Canyon Lake was about 3.5 feet at site 10, 4.5 feet at site 9 , and 9 feet near the dam (site 11) during the study period. As a shallow lake with a short residence time (about 48 hours), Canyon Lake is not likely to stratify, and the water column was fairly uniform with respect to water-quality characteristics. Table 1 shows a depth profile of field waterquality measurements for the lake (site 11) on May 8, 2007.

\section{Sampling Sites}

Stream sampling locations were established at USGS stations on Rapid Creek from below Pactola Dam downstream to the station at the WTP (fig. 1), and at six established Canyon Lake sites (fig. 2). Retention ponds below both Pactola Dam and Canyon Lake Dam also were sampled. Table 2 includes a description of the sampling locations and the types of samples collected.

\section{Rapid Creek Streamflow}

Daily mean streamflow for Rapid Creek above Canyon Lake (USGS station number 06412500) for the 2007 water year (WY) is shown in figure 3 (U.S. Geological Survey, 2007). Sampling on Rapid Creek occurred just prior to and immediately following increased flows to meet downstream irrigation water demands. The daily mean streamflow for both the May and September sampling events was between 10 and $20 \mathrm{ft}^{3} / \mathrm{s}$, whereas the peak daily mean streamflow for WY 2007 was $93 \mathrm{ft}^{3} / \mathrm{s}$, which occurred on July 8, 2007.

\section{Methods of Study}

Biological samples were collected from Rapid Creek and Canyon Lake and analyzed to determine the algal community assemblage in the water column (phytoplankton) and attached to the stream or lake bottom (periphyton) during May and September 2007. Algal taxa were identified from samples collected in three distinct data sets: quantitative phytoplankton, quantitative periphyton, and qualitative periphyton. Qualitative sample results can only be used to determine the presence or absence of an organism, whereas cell density, biovolume, and relative abundance (percent of total biovolume) can be determined from quantitative samples. During May 2007, 3 Rapid Creek sites (map reference numbers 3, 13, and 16 in table 2) and 4 Canyon Lake sites (9-12) were sampled for phytoplankton, 7 Rapid Creek sites (2-5 and 13-15) were quantitatively sampled for periphyton, and 4 lake/retention pond sites (1, 8, 9 , and 11) were qualitatively sampled for periphyton. Samples 


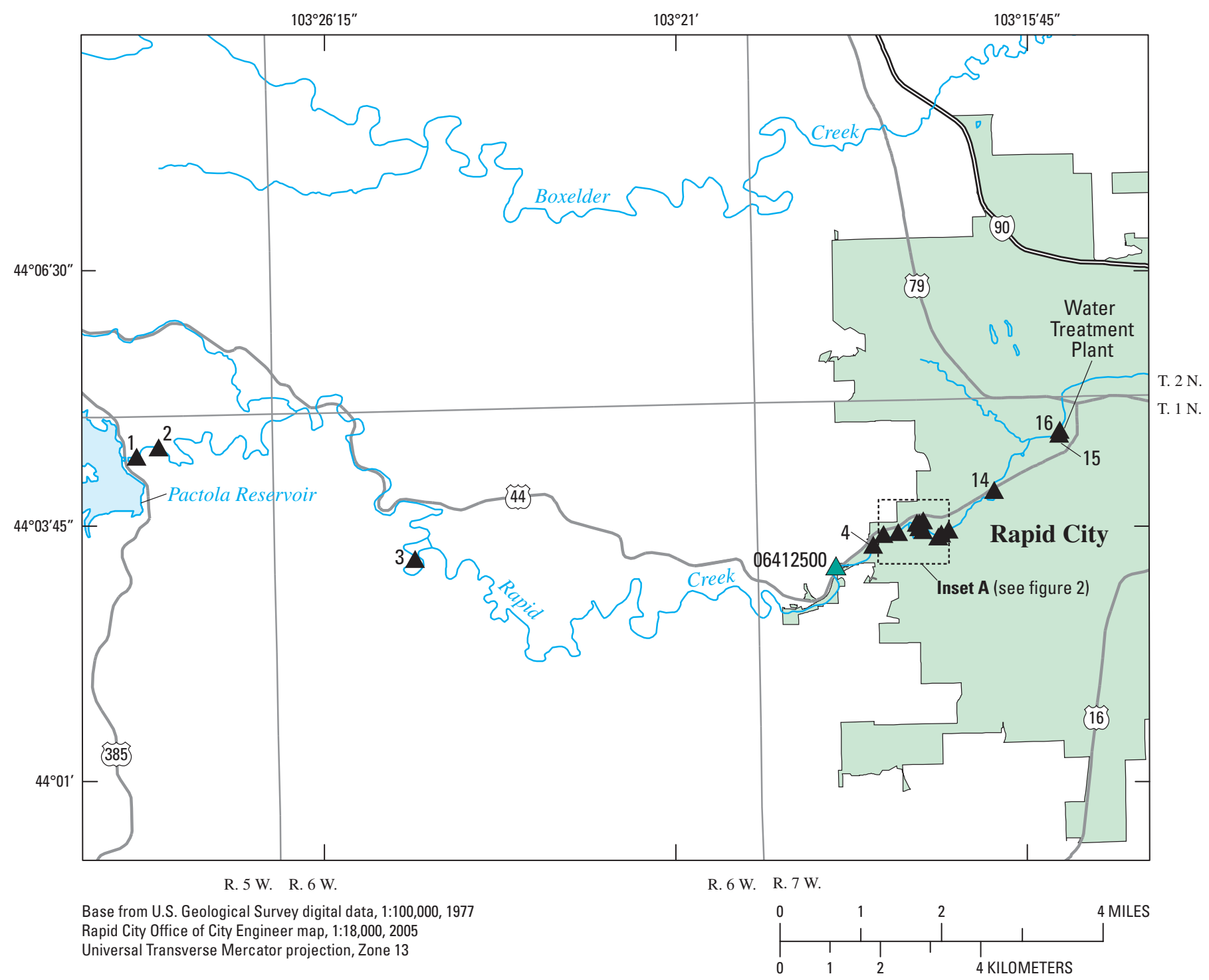

\section{EXPLANATION}

Sampling site and map reference number from table 1 06412500

Continuous-record streamflow-gaging station and station number

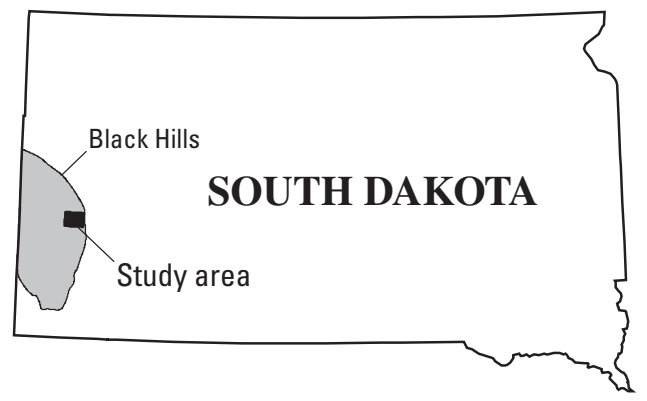

Figure 1. Locations of sites for algae and water-quality sampling, 2007. 


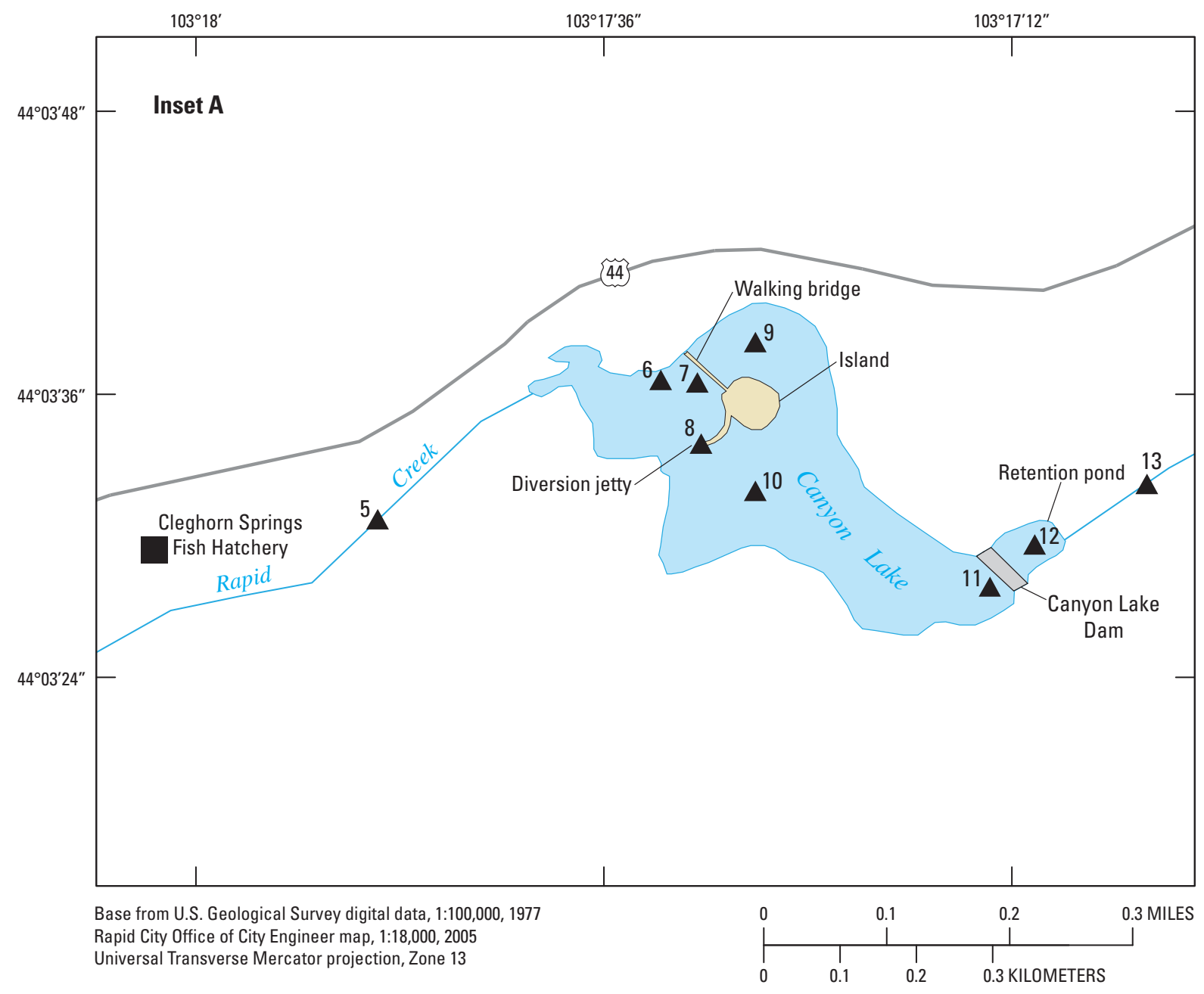

EXPLANATION

$\Delta^{6}$ Sampling site and map reference number from table 1

Figure 2. Locations of sites for algae and water-quality sampling near Canyon Lake, 2007 (see figure 1, insert A).

Table 1. Depth profile of field water-quality measurements at Canyon Lake (site 11), May 8, 2007.

$\left[{ }^{\circ} \mathrm{C}\right.$, degrees Celsius; $\mathrm{mg} / \mathrm{L}$, milligrams per liter; $\mu \mathrm{S} / \mathrm{cm}$, microsiemens per centimeter at $\left.25^{\circ} \mathrm{C}\right]$

\begin{tabular}{ccccc}
\hline $\begin{array}{c}\text { Depth from surface }{ }^{\mathbf{1}} \\
\text { (feet) }\end{array}$ & $\begin{array}{c}\text { Water temperature } \\
\left({ }^{\circ} \mathbf{C}\right)\end{array}$ & $\begin{array}{c}\text { Dissolved oxygen } \\
(\mathbf{m g} / \mathbf{L})\end{array}$ & $\begin{array}{c}\text { pH } \\
\text { (standard units) }\end{array}$ & $\begin{array}{c}\text { Specific conductance } \\
(\boldsymbol{\mu S} \mathbf{S} / \mathbf{c m})\end{array}$ \\
\hline 1 & 13.1 & 14.9 & 8.7 & 373 \\
3 & 12.8 & 14.6 & 8.6 & 376 \\
5 & 12.5 & 15.0 & 8.6 & 381 \\
7 & 12.2 & 15.4 & 8.6 & 383 \\
\hline
\end{tabular}

${ }^{1}$ Maximum depth at site was 9 feet. 
Table 2. List of sites sampled in study, 2007.

[QL, qualitative periphyton; QN, quantitative periphyton; GS, geosmin; MIB, 2-methylisoborneol; PY, quantitative phytoplankton; WTP, water treatment plant; ACT, actinomycetes]

\begin{tabular}{|c|c|c|c|c|c|c|c|}
\hline \multirow{2}{*}{$\begin{array}{l}\text { Map } \\
\text { reference } \\
\text { number }\end{array}$} & \multirow[b]{2}{*}{ Site name } & \multirow{2}{*}{$\begin{array}{c}\text { Station } \\
\text { identification } \\
\text { number }\end{array}$} & \multirow[b]{2}{*}{ Other identifier } & Latitude & Longitude & \multirow{2}{*}{$\begin{array}{l}\text { Sample } \\
\text { type(s) } \\
\text { collected }\end{array}$} & \multirow[b]{2}{*}{ Sampling location } \\
\hline & & & & \multicolumn{2}{|c|}{$\begin{array}{c}\text { (degrees, minutes, } \\
\text { seconds) }\end{array}$} & & \\
\hline 3 & $\begin{array}{l}\text { Rapid Creek at Big } \\
\text { Bend near Rapid } \\
\text { City }\end{array}$ & 06412000 & Big Bend & $44^{\circ} 03^{\prime} 18^{\prime \prime}$ & $103^{\circ} 25^{\prime} 00^{\prime \prime}$ & $\begin{array}{l}\text { QN, PY, } \\
\text { GS, } \\
\text { MIB }\end{array}$ & $\begin{array}{l}\text { Approximately } \\
100 \text { feet upstream } \\
\text { from bridge } \\
\text { crossing. }\end{array}$ \\
\hline 6 & $\begin{array}{l}\text { Canyon Lake at north } \\
\text { shore at Rapid City }\end{array}$ & 440336103173200 & $\begin{array}{l}\text { Canyon Lake } \\
\text { north shore }\end{array}$ & $44^{\circ} 03^{\prime} 36^{\prime \prime}$ & $103^{\circ} 17^{\prime} 32^{\prime \prime}$ & QL & $\begin{array}{l}\text { Approximately } \\
50 \text { feet in lake from } \\
\text { northwest shore and } \\
100 \text { feet southwest } \\
\text { of walking bridge. }\end{array}$ \\
\hline 7 & $\begin{array}{l}\text { Canyon Lake near } \\
\text { north shore at Rapid } \\
\text { City }\end{array}$ & 440335103173100 & $\begin{array}{c}\text { Canyon Lake } \\
\text { vegetation }\end{array}$ & $44^{\circ} 03^{\prime} 35^{\prime \prime}$ & $103^{\circ} 17^{\prime} 31^{\prime \prime}$ & QL & $\begin{array}{l}\text { Approximately } \\
100 \text { feet in lake } \\
\text { from northwest } \\
\text { shore and } 50 \\
\text { feet southwest of } \\
\text { walking bridge. }\end{array}$ \\
\hline 9 & $\begin{array}{l}\text { Canyon Lake } \mathrm{N} \text { island } \\
\text { at Rapid City }\end{array}$ & 440340103172900 & $\begin{array}{l}\text { Canyon Lake } \\
\text { north }\end{array}$ & $44^{\circ} 03^{\prime} 40^{\prime \prime}$ & $103^{\circ} 17^{\prime} 29^{\prime \prime}$ & QL, PY & $\begin{array}{l}\text { Transect from south } \\
\text { tip of island to } \\
\text { south boundary of } \\
\text { lake. }\end{array}$ \\
\hline 10 & $\begin{array}{l}\text { Canyon Lake SE island } \\
\text { at Rapid City }\end{array}$ & 440331103172300 & $\begin{array}{l}\text { Canyon Lake } \\
\text { south }\end{array}$ & $44^{\circ} 03^{\prime} 31^{\prime \prime}$ & $103^{\circ} 17^{\prime} 23^{\prime \prime}$ & PY & $\begin{array}{l}\text { Transect from north } \\
\text { tip of island to north } \\
\text { boundary of lake. }\end{array}$ \\
\hline 11 & $\begin{array}{l}\text { Canyon Lake at Rapid } \\
\text { City }\end{array}$ & 06413100 & $\begin{array}{l}\text { Canyon Lake } \\
\text { Dam }\end{array}$ & $44^{\circ} 03^{\prime} 27^{\prime \prime}$ & $103^{\circ} 17^{\prime} 13^{\prime \prime}$ & $\begin{array}{l}\text { QL, PY, } \\
\text { GS, } \\
\text { MIB }\end{array}$ & $\begin{array}{l}\text { Transect approxi- } \\
\text { mately } 100 \text { feet } \\
\text { parallel to dam to } \\
\text { the southwest. }\end{array}$ \\
\hline 12 & $\begin{array}{l}\text { Retention pond below } \\
\text { Canyon Lake at } \\
\text { Rapid City }\end{array}$ & 440328103171100 & $\begin{array}{l}\text { Canyon Lake } \\
\text { retention } \\
\text { pond }\end{array}$ & $44^{\circ} 03^{\prime} 28^{\prime \prime}$ & $103^{\circ} 17^{\prime} 11^{\prime \prime}$ & PY & $\begin{array}{l}\text { Approximately } \\
100 \text { feet down- } \\
\text { stream from dam. }\end{array}$ \\
\hline 13 & $\begin{array}{l}\text { Rapid Creek below } \\
\text { Park Drive, at Rapid } \\
\text { City }\end{array}$ & 06413200 & Park Drive & $44^{\circ} 03^{\prime} 33^{\prime \prime}$ & $103^{\circ} 17^{\prime} 02^{\prime \prime}$ & $\begin{array}{l}\text { QN, PY, } \\
\text { GS, } \\
\text { MIB }\end{array}$ & $\begin{array}{l}\text { Approximately } \\
200 \text { feet upstream } \\
\text { from Park Drive. }\end{array}$ \\
\hline
\end{tabular}


Table 2. List of sites sampled in study, 2007. — Continued

[QL, qualitative periphyton; QN, quantitative periphyton; GS, geosmin; MIB, 2-methylisoborneol; PY, quantitative phytoplankton; WTP, water treatment plant; ACT, actinomycetes]

\begin{tabular}{|c|c|c|c|c|c|c|c|}
\hline $\begin{array}{c}\text { Map } \\
\text { reference } \\
\text { number }\end{array}$ & Site name & $\begin{array}{c}\text { Station } \\
\text { identification } \\
\text { number }\end{array}$ & Other identifier & Latitude & Longitude & $\begin{array}{l}\text { Sample } \\
\text { type(s) } \\
\text { collected }\end{array}$ & Sampling location \\
\hline 16 & $\begin{array}{l}\text { Rapid Creek at WTP at } \\
\text { Rapid City }\end{array}$ & 06413720 & At WTP & $44^{\circ} 04^{\prime} 33^{\prime \prime}$ & $103^{\circ} 15^{\prime} 21^{\prime \prime}$ & $\begin{array}{c}\text { PY, GS, } \\
\text { MIB, } \\
\text { ACT }\end{array}$ & At WTP intake. \\
\hline
\end{tabular}

${ }^{1}$ Station identification number not established.

collected from 4 Rapid Creek sites (2, 3, 13, and 16) and site 11 on Canyon Lake were analyzed for the taste-and-odor causing compounds geosmin and MIB. One water sample was collected at the WTP site (16) on Rapid Creek and analyzed for actinomycetes bacteria. In September 2007, quantitative periphyton sampling was performed at 4 Rapid Creek sites $(2,4,13$, and 15$)$, and qualitative sampling was performed at 3 Canyon Lake sites (6-8).

\section{Field Methods}

Grab samples for phytoplankton, geosmin, MIB, and actinomycetes bacteria were collected from the centroid of the stream by using brown high-density polyethylene (HDPE) bottles for phytoplankton, baked amber glass bottles for geosmin and MIB, and sterile HDPE bottles for actinomycetes samples. At site 16, a thief sampling method was used with a brass Kemmerer bottle because high water depths prevented the collection of grab samples by wading. Nonisokinetic sampling methods (such as grab and thief samples) generally do not result in a discharge-weighted sample unless the stream is completely mixed laterally and vertically (U.S. Geological Survey, 2006). Rapid Creek was assumed to have adequate mixing laterally and vertically because it is a shallow, narrow stream with turbulent velocity. Open-mouth grab samples may be the only sampling method possible in this type of stream (Hambrook Berkman and Canova, 2007). A depth-integrating sampling technique utilizing 3/4-inch Masterflex tubing and a check valve was used to collect water samples for enumeration of phytoplankton from Canyon Lake (sites 9-12). This approach allowed a depth-integrated sample of the entire water column to be collected. Field water-quality measurements (water temperature, dissolved oxygen, $\mathrm{pH}$, and specific conductance) were recorded at each sampling site with the use of a multiparameter probe (YSI model \#600XL) calibrated before and after use according to manufacturer's recommendations.

Methods similar to those described in Moulton and others (2002) and Hambrook Berkman and Canova (2007) were used in sampling stream sites (2-5 and 13-15) quantitatively for periphyton. Three cobbles were randomly selected for periphyton sampling at each of three representative riffles/runs at the sampling site (total of 9 cobbles per site). The periphyton from a particular area on the top of each cobble was scraped into a dishpan by the use of a small brush and rinsed off with filtered stream water. The volume of algal biomass and rinse water was measured in a graduated cylinder before transfer into brown HDPE sample bottles and preservation with 9:1 Lugol's iodine: acetic acid solution. Aluminum foil was wrapped around the surface of each cobble from which periphyton was collected. The areas of these foils were calculated later to determine the actual stream areas from which the samples were collected.

For sites sampled qualitatively for periphyton presence/ absence, algal biomass was scraped from the desired substrate into a large dishpan before collection in brown HDPE bottles and preservation with a 9:1 Lugol's iodine: acetic acid solution. Sites with cobble-to-boulder sized rocks were sampled by scraping the majority of biomass from the top of 5-10 rocks. Canyon Lake sediment was collected by using an Ekman sediment sampler. Epiphytic periphyton was sampled from aquatic vegetation by brushing the grassy submerged macrophytes and collecting the algal material into a plastic basin. During the May sampling period, periphyton was sampled from the flow diversion jetty (in the middle of Canyon Lake; site 8), from the north side (site 9), and near the dam (site 11). The fourth qualitative periphyton sample was collected from the retention pond downstream from Pactola Dam (site 1), where proliferations of filamentous green algae were observed. In September, rocks of the Canyon Lake jetty 


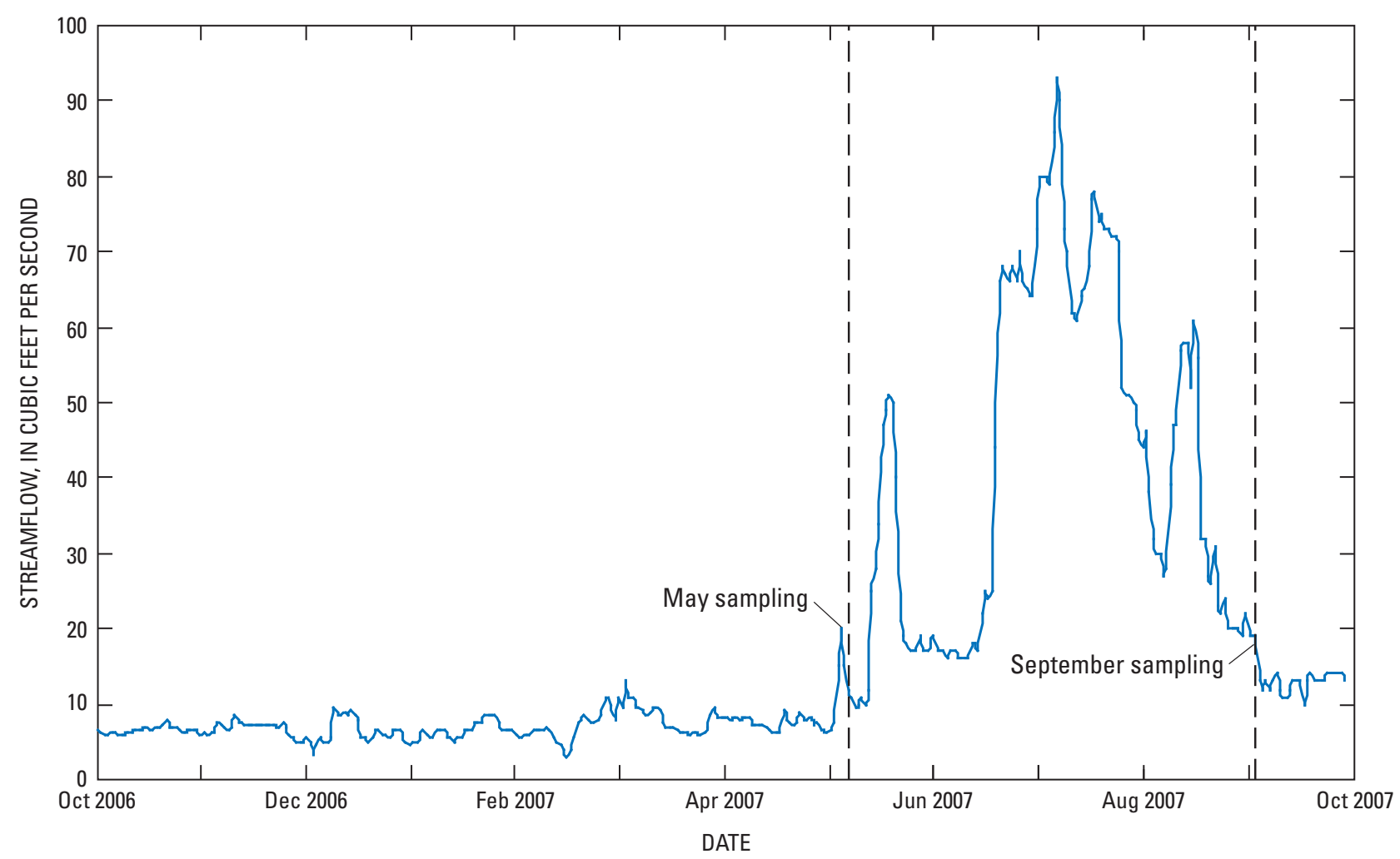

Figure 3. Daily mean streamflow for station 06412500 (Rapid Creek above Canyon Lake near Rapid City, SD) for water year 2007 (October 1, 2006-September 30, 2007; U.S. Geological Survey, 2007).

were again sampled qualitatively, as were rocks and vegetation along the shallow north shore near the walking bridge (sites 6-8).

\section{Laboratory Methods}

All phytoplankton and periphyton (quantitative and qualitative) identification and enumeration were performed by BSA Environmental Services, Beachwood, Ohio. Slides of phytoplankton were made by using the standard membrane filtration technique described by McNabb (1960). Both diatom and soft (non-diatom) algal units were enumerated to the lowest possible taxonomic level, with a minimum of 400 natural units counted per sample. Biovolume factors were calculated by using the methods described in Hillenbrand and others (1999). The soft algae in the quantitative periphyton samples were first enumerated to the lowest possible taxonomic level using membrane filtered slides (McNabb, 1960), with a minimum of 400 natural units counted. Diatoms were counted as a general category, and then examined more closely in permanent diatom mounts to determine species identifications. Diatom slides were made by using the traditional nitric acid digestion method as described in Academy of Natural Sciences Protocol No. P-13-02 (Patrick Center for Environmental Research, 1988). A minimum of 400 valves were identified to the lowest possible taxonomic level. Biovolume factors for both soft algae and diatoms were calculated by using the methods described in Hillenbrand and others (1999). Membrane filtered slides were made for each of the qualitative periphyton samples, and a minimum of 400 natural units (including both soft algae and diatoms) were counted to the lowest possible taxonomic unit (McNabb, 1960).

Geosmin and MIB were analyzed at the USGS Organic Geochemistry Research Laboratory in Lawrence, Kansas, by gas chromatography/mass spectrometry (Zimmerman and others, 2002). Suspended particulate matter was removed from the samples by filtration, so the method measured only dissolved-phase compounds. The reporting level for these analyses was $0.005 \mu \mathrm{g} / \mathrm{L}$. Actinomycetes were analyzed by the USGS Microbiological Laboratory in Columbus, Ohio, with the use of a double-layer agar-plating method (Eaton and others, 1995). 


\section{Algal and Water Quality Data}

\section{Field Measurements}

Field measurements are reported for each sampling site (table 3). Water temperatures of Rapid Creek sites during the September sampling period averaged $5.3^{\circ} \mathrm{C}$ (range: $10.7-21.2^{\circ} \mathrm{C}$ ) higher than during the May sampling period (range: $7.4-13.6^{\circ} \mathrm{C}$ ). Water temperatures of Canyon Lake sites during the September sampling period averaged $0.5^{\circ} \mathrm{C}$ lower than during the May sampling period. The $\mathrm{pH}$ of water samples ranged from 6.6 to $9.0($ mean $=7.4)$ in all water samples. Dissolved oxygen ranged from 9.9 to $16.4 \mathrm{mg} / \mathrm{L}$ $($ mean $=13.2 \mathrm{mg} / \mathrm{L})$, and specific conductance ranged from 374 to $491 \mu \mathrm{S} / \mathrm{cm}$ (mean $=413 \mu \mathrm{S} / \mathrm{cm})$.

\section{Algae}

Data for quantitative phytoplankton, quantitative periphyton, and qualitative periphyton are presented in the Appendix. The algal community composition summaries presented in tables 4-6 are based on the relative abundance of each algal division. Relative abundance refers to the percentage of total biovolume that the specific division (or genera) occupies in the sample. Diatoms (division Bacillariophyta) were the dominant algal taxa in all the samples, making up greater than 90 percent of the total algal biovolume. Three of the seven phytoplankton samples collected in May contained cyanobacteria (table 4), but the relative biovolumes were small (0.01-0.2 percent). Cyanobacteria were present in 3 of the 7 quantitative periphyton samples collected in May (table 5), and in all 4 of the samples collected in September (table 6).
The cyanobacteria present in the seven quantitative periphyton samples in May and September ranged from 0.01 to 2.0 percent of the total biovolume. In May, three of the four qualitative periphyton samples contained cyanobacteria, and in September all three samples collected from Canyon Lake contained cyanobacteria.

The general dominance of the algal taxa Cyclostephanos, Fragilaria, Navicula, Cyclotella, and Cymbella in samples was indicative of mesotrophic to eutrophic conditions, and these organisms are normally sensitive to nutrient enrichment (not pollution tolerant). Exceptions to these conditions were at those sites with Synedra or Melosira as the dominant algal taxa, as these organisms generally are more pollution tolerant and prefer conditions with low dissolved oxygen (about 50 percent of saturation) and higher biochemical oxygen demand (4-22 mg/L BOD ${ }_{5}$; Porter, 2008).

During this study, no taste-and-odor problems with the drinking water within the study area were reported. However, the presence of cyanobacterial taxa known to contain tasteand-odor producing strains (such as Leptolyngbya, Phormidium, and Anabaena) indicates the potential for taste-and-odor problems under certain physical and chemical conditions (Taylor and others, 2006; Graham and others, 2008).

\section{Water Quality}

Results of water-quality sample analyses are shown in table 7. Geosmin and MIB concentrations were less than reporting levels $(0.005 \mu \mathrm{g} / \mathrm{L})$ in all five of the Rapid Creek samples collected in May. The concentration of actinomycetes bacteria in the sample collected near the WTP intake in May was $6 \mathrm{col} / \mathrm{mL}$. 
Table 3. Field water-quality measurements for sampling sites, 2007.

$\left[{ }^{\circ} \mathrm{C}\right.$, degrees Celsius; $\mu \mathrm{S} / \mathrm{cm}$, microsiemens per centimeter at $25^{\circ} \mathrm{C} ; \mathrm{mg} / \mathrm{L}$, milligrams per liter; --, no data available; WTP, water treatment plant $]$

\begin{tabular}{|c|c|c|c|c|c|c|c|c|c|}
\hline $\begin{array}{c}\text { Map } \\
\text { reference } \\
\text { number }\end{array}$ & Site name & $\begin{array}{c}\text { Site identification } \\
\text { number }\end{array}$ & Other identifier & Date & Time & $\begin{array}{c}\text { Temperature } \\
\left({ }^{\circ} \mathrm{C}\right)\end{array}$ & $\begin{array}{c}\text { pH } \\
\text { (standard } \\
\text { units) }\end{array}$ & 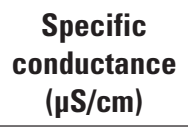 & $\begin{array}{c}\text { Dissolved } \\
\text { oxygen } \\
\text { (mg/L) }\end{array}$ \\
\hline \multicolumn{10}{|c|}{ May sampling } \\
\hline 1 & $\begin{array}{l}\text { Rapid Creek retention pond } \\
\text { below Pactola Dam }\end{array}$ & $\left({ }^{1}\right)$ & $\begin{array}{l}\text { Pactola retention } \\
\text { pond }\end{array}$ & $5 / 10 / 2007$ & 930 & -- & -- & -- & -- \\
\hline 2 & Rapid Creek below Pactola Dam ${ }^{2}$ & 06411500 & Pactola Dam & $5 / 10 / 2007$ & 930 & 7.5 & 7.8 & 401 & 11.5 \\
\hline 3 & $\begin{array}{l}\text { Rapid Creek at Big Bend near } \\
\text { Rapid City }{ }^{2}\end{array}$ & 06412000 & Big Bend & $5 / 9 / 2007$ & 1400 & 17.2 & 8.4 & 406 & 13.3 \\
\hline 4 & $\begin{array}{l}\text { Rapid Creek at Braeburn } \\
\text { addition near Rapid City² }\end{array}$ & 440321103181101 & Braeburn & $5 / 10 / 2007$ & 745 & 11.0 & 7.4 & 417 & 9.9 \\
\hline 5 & $\begin{array}{l}\text { Rapid Creek below Cleghorn } \\
\text { Springs at Rapid City }{ }^{2}\end{array}$ & 06412900 & Cleghorn Springs & $5 / 9 / 2007$ & 1020 & 11.5 & 8.0 & 400 & 12.6 \\
\hline 8 & $\begin{array}{l}\text { Canyon Lake near jetty at Rapid } \\
\text { City }\end{array}$ & 440332103173100 & Canyon Lake jetty & $5 / 8 / 2007$ & 1630 & -- & -- & -- & -- \\
\hline 9 & $\begin{array}{l}\text { Canyon Lake } \mathrm{N} \text { island at Rapid } \\
\text { City }\end{array}$ & 440340103172900 & Canyon Lake north & $5 / 8 / 2007$ & 1520 & 15.2 & 8.5 & 390 & 12.7 \\
\hline 10 & $\begin{array}{l}\text { Canyon Lake SE island at Rapid } \\
\text { City }\end{array}$ & 440331103172300 & Canyon Lake south & $5 / 8 / 2007$ & 1325 & 15.0 & 8.7 & 384 & 16.4 \\
\hline 11 & Canyon Lake at Rapid City & 06413100 & Canyon Lake dam & $5 / 8 / 2007$ & 1415 & 12.7 & 8.6 & 378 & 14.8 \\
\hline 12 & $\begin{array}{l}\text { Retention pond below Canyon } \\
\text { Lake at Rapid City }\end{array}$ & 440328103171100 & $\begin{array}{l}\text { Canyon Lake } \\
\text { retention pond }\end{array}$ & $5 / 9 / 2007$ & 935 & 14.8 & 9.0 & 382 & 15.2 \\
\hline 13 & $\begin{array}{l}\text { Rapid Creek below Park Drive, } \\
\text { at Rapid City }{ }^{2}\end{array}$ & 06413200 & Park Drive & $5 / 9 / 2007$ & 1230 & 15.8 & 8.3 & 374 & 13.6 \\
\hline 14 & $\begin{array}{l}\text { Rapid Creek above Jackson } \\
\text { Blvd, at Rapid City }{ }^{2}\end{array}$ & 06413570 & Jackson Blvd. & $5 / 9 / 2007$ & 830 & 13.6 & 8.3 & 385 & 14.3 \\
\hline 15 & $\begin{array}{l}\text { Rapid Creek above WTP at } \\
\text { Rapid City }{ }^{2}\end{array}$ & 06413700 & Above WTP & $5 / 8 / 2007$ & 958 & 12.9 & 8.1 & 483 & 12.9 \\
\hline 16 & $\begin{array}{l}\text { Rapid Creek at WTP at Rapid } \\
\text { City }\end{array}$ & 06413720 & At WTP & $5 / 8 / 2007$ & 920 & 11.9 & 7.2 & 491 & 12.7 \\
\hline
\end{tabular}


Table 3. Field water-quality measurements for sampling sites, 2007. —Continued

$\left[{ }^{\circ} \mathrm{C}\right.$, degrees Celsius; $\mu \mathrm{S} / \mathrm{cm}$, microsiemens per centimeter at $25^{\circ} \mathrm{C} ; \mathrm{mg} / \mathrm{L}$, milligrams per liter; --, no data available; WTP, water treatment plant $]$

\begin{tabular}{|c|c|c|c|c|c|c|c|c|c|}
\hline $\begin{array}{l}\text { Map } \\
\text { reference } \\
\text { number }\end{array}$ & Site name & $\begin{array}{c}\text { Site identification } \\
\text { number }\end{array}$ & Other identifier & Date & Time & $\begin{array}{c}\text { Temperature } \\
\left({ }^{\circ} \mathrm{C}\right)\end{array}$ & $\begin{array}{c}\text { pH } \\
\text { (standard } \\
\text { units) }\end{array}$ & 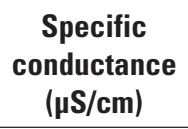 & $\begin{array}{c}\text { Dissolved } \\
\text { oxygen } \\
\text { (mg/L) }\end{array}$ \\
\hline \multicolumn{10}{|c|}{ September sampling } \\
\hline 2 & Rapid Creek below Pactola Dam² & 06411500 & Pactola Dam & $9 / 5 / 2007$ & 1145 & 10.7 & -- & 408 & -- \\
\hline 4 & $\begin{array}{l}\text { Rapid Creek at Braeburn } \\
\text { addition near Rapid City }\end{array}$ & 440321103181101 & Braeburn & $9 / 4 / 2007$ & 1430 & 21.2 & 7.5 & 411 & 10.0 \\
\hline 6 & $\begin{array}{l}\text { Canyon Lake at north shore at } \\
\text { Rapid City }\end{array}$ & 440336103173200 & $\begin{array}{l}\text { Canyon Lake north } \\
\text { shore }\end{array}$ & $9 / 10 / 2007$ & 1345 & 14.2 & 7.7 & 421 & 15.7 \\
\hline 7 & $\begin{array}{l}\text { Canyon Lake near north shore at } \\
\text { Rapid City }\end{array}$ & 440335103173100 & $\begin{array}{c}\text { Canyon Lake } \\
\text { vegetation }\end{array}$ & $9 / 10 / 2007$ & 1400 & 13.9 & 7.8 & 410 & 14.5 \\
\hline 8 & $\begin{array}{l}\text { Canyon Lake near jetty at Rapid } \\
\text { City }\end{array}$ & 440332103173100 & Canyon Lake jetty & 9/10/2007 & 1330 & 13.8 & 6.6 & 428 & 16.4 \\
\hline 13 & $\begin{array}{l}\text { Rapid Creek below Park Drive, } \\
\text { at Rapid City }{ }^{2}\end{array}$ & 06413200 & Park Drive & $9 / 4 / 2007$ & 1320 & 20.2 & 7.5 & 416 & 10.2 \\
\hline 16 & $\begin{array}{l}\text { Rapid Creek above WTP at } \\
\text { Rapid City }{ }^{2}\end{array}$ & 06413700 & Above WTP & $9 / 4 / 2007$ & 1145 & 20.1 & 6.7 & 465 & 11.5 \\
\hline
\end{tabular}

${ }^{1}$ Station identification number not established.

${ }^{2}$ Values reported for quantitative periphyton sites are average values of three transects. 
Table 4. Relative abundance of algal divisions (percent of total biovolume) in phytoplankton samples collected during May 2007.

[WTP, water treatment plant; --, not identified in sample]

\begin{tabular}{llcccccccc}
\hline & & \multicolumn{6}{c}{ Relative abundance (in percent) by other identifier (map reference number) } \\
\cline { 3 - 9 } Algal division & Common name & $\begin{array}{c}\text { At WTP } \\
(\mathbf{1 6 )}\end{array}$ & $\begin{array}{c}\text { Park Drive } \\
\mathbf{( 1 3 )}\end{array}$ & $\begin{array}{c}\text { Canyon Lake } \\
\text { retention pond } \\
\text { (12) }\end{array}$ & $\begin{array}{c}\text { Canyon Lake } \\
\text { south } \\
(\mathbf{1 0 )}\end{array}$ & $\begin{array}{c}\text { Canyon Lake } \\
\text { north } \\
\text { (9) }\end{array}$ & $\begin{array}{c}\text { Canyon Lake } \\
\text { Dam } \\
\text { (11) }\end{array}$ & $\begin{array}{c}\text { Big Bend } \\
\text { (3) }\end{array}$ \\
\hline Bacillariophyta & Diatoms & 99.3 & 97.5 & 97.5 & 99.8 & 99.9 & 99.8 & 97.6 \\
Chlorophyta & Green algae & .43 & 2.5 & 2.2 & .17 & .06 & .18 & 1.9 \\
Cyanophyta & Cyanobacteria & .23 & -- & .09 & -- & .01 & -- & -- \\
Chrysophyta & Golden algae & .03 & -- & -- & -- & -- & -- & -- \\
Cryptophyta & Cryptophytes & -- & -- & .16 & -- & -- & .03 & -- \\
Pyrrophyta & Dinoflagellates & -- & -- & -- & -- & -- & -- & .49 \\
\hline
\end{tabular}

Table 5. Relative abundance of algal divisions (percent of total biovolume) in quantitative periphyton samples collected during May 2007.

[WTP, water treatment plant; --, not identified in sample]

\begin{tabular}{llccccccc}
\hline & & \multicolumn{6}{c}{ Relative abundance (in percent) by other identifier (map reference number) } \\
\cline { 3 - 8 } Algal division & Common name & $\begin{array}{c}\text { Above WTP } \\
(\mathbf{1 5 )}\end{array}$ & $\begin{array}{c}\text { Jackson Blvd. } \\
\text { (14) }\end{array}$ & $\begin{array}{c}\text { Park Drive } \\
\mathbf{( 1 3 )}\end{array}$ & $\begin{array}{c}\text { Cleghorn } \\
\text { Springs } \\
\mathbf{( 5 )}\end{array}$ & $\begin{array}{c}\text { Braeburn } \\
\text { (4) }\end{array}$ & $\begin{array}{c}\text { Big Bend } \\
\text { (3) }\end{array}$ & $\begin{array}{c}\text { Pactola Dam } \\
\text { (2) }\end{array}$ \\
\hline Bacillariophyta & Diatoms & 100 & 100 & 99.5 & 97.4 & 96.2 & 99.7 & 99.4 \\
Chlorophyta & Green algae & -- & -- & .46 & 2.4 & 3.5 & .33 & .55 \\
Cyanophyta & Cyanobacteria & -- & -- & -- & .22 & .25 & .01 & -- \\
Pyrrophyta & Dinoflagellates & -- & -- & -- & -- & -- & -- & .02 \\
\hline
\end{tabular}

Table 6. Relative abundance of algal divisions (percent of total biovolume) in quantitative periphyton samples collected during September 2007.

[WTP, water treatment plant; --, not identified in sample]

\begin{tabular}{llcccc}
\hline \multirow{2}{*}{ Algal division } & Common name & \multicolumn{4}{c}{ Relative abundance (in percent) by other identifier (map reference number) } \\
\cline { 3 - 6 } & & $\begin{array}{c}\text { Above WTP } \\
\text { (15) }\end{array}$ & $\begin{array}{c}\text { Park Drive } \\
\text { (13) }\end{array}$ & $\begin{array}{c}\text { Braeburn } \\
\text { (4) }\end{array}$ & $\begin{array}{c}\text { Pactola Dam } \\
\text { (2) }\end{array}$ \\
\hline Bacillariophyta & Diatoms & 96.7 & 93.3 & 96.1 & 90.9 \\
Chlorophyta & Green algae & 3.0 & 6.5 & 2.0 & 8.5 \\
Cyanophyta & Cyanobacteria & .34 & .13 & 2.0 & .61 \\
Euglenophyta & Euglenoids & -- & .03 & -- & .01 \\
\hline
\end{tabular}


Table 7. Water-quality data for samples analyzed for geosmin, 2-methylisoborneol (MIB), and actinomycetes, 2007.

[ $\mu \mathrm{g} / \mathrm{L}$, micrograms per liter; col/mL, colonies per milliliter; <, less than; --, not sampled; WTP, water treatment plant]

\begin{tabular}{|c|c|c|c|c|c|}
\hline $\begin{array}{c}\text { Station } \\
\text { identification } \\
\text { number }\end{array}$ & Other identifier & Date & $\begin{array}{l}\text { Geosmin } \\
(\mu \mathrm{g} / \mathrm{L})\end{array}$ & $\begin{array}{c}\text { MIB } \\
(\mu \mathrm{g} / \mathrm{L})\end{array}$ & $\begin{array}{l}\text { Actinomycetes } \\
(\text { col } / \mathrm{mL})\end{array}$ \\
\hline 06411500 & Pactola Dam & $5 / 10 / 2007$ & $<0.005$ & $<0.005$ & -- \\
\hline 06412000 & Big Bend & $5 / 9 / 2007$ & $<.005$ & $<.005$ & -- \\
\hline 06413100 & Canyon Lake Dam & $5 / 8 / 2007$ & $<.005$ & $<.005$ & -- \\
\hline 06413200 & Park Drive & $5 / 9 / 2007$ & $<.005$ & $<.005$ & -- \\
\hline 06413720 & At WTP & $5 / 8 / 2007$ & $<.005$ & $<.005$ & 6 \\
\hline
\end{tabular}

\section{References Cited}

Driscoll, D.G., Bradford, W.L., and Moran, M.J., 2000, Selected hydrologic data, through water year 1998, Black Hills Hydrology Study, South Dakota: U.S. Geological Survey Open-File Report 00-70, 284 p., accessed May 27, 2008, at http://pubs.usgs.gov/of/2000/ofr0070/.

Eaton, A.D., Clesceri, L.S., and Greenberg, A.E., 1995, Standard methods for the examination of water and wastewater (19th ed.): Washington, D.C., American Public Health Association, various pagination.

Graham, J.L., Loftin, K.A., Ziegler, A.C., and Meyer, M.T., 2008, Guidelines for design and sampling for cyanobacterial toxin and taste-and-odor studies in lakes and reservoirs: U.S. Geological Survey Scientific Investigations Report 2008-5038, 52 p., accessed May 27, 2008, at http://pubs.usgs.gov/sir/2008/5038/.

Hambrook Berkman, J.A., and Canova, M.G., 2007, Algal biomass indicators (ver. 1.0): U.S. Geological Survey Techniques of Water-Resources Investigations, book 9, chap. A7, section 7.4, August, available online only from http://pubs.water.usgs.gov/twri9A/.

Hillenbrand, Helmut, Dürselen, C.D., Kirschtel, David, Pollingher, Utsa, and Zohary, Tamar, 1999, Biovolume calculation for pelagic and benthic microalgae: Journal of Phycology, v. 35, no. 2, p. 403-424.

Mallevialle, J., and Suffet, I.H., eds., 1987, Identification and treatment of tastes and odors in drinking water: Denver, Colo., American Water Works Association Research Foundation, Cooperative Research Report, 292 p.

McNabb, C.D., 1960, Enumeration of freshwater phytoplankton concentrated on the membrane filter: Limnology and Oceanography, v. 5, no. 1, p. 57-61.
Moulton, S.R., II, Kennen, J.G., Goldstein, R.M., Hambrook, J.A., 2002, Revised protocols for sampling algal, invertebrate, and fish communities as part of the National WaterQuality Assessment Program: U.S. Geological Survey Open-File Report 02-150, 75 p., accessed May 27, 2008, at http://water.usgs.gov/nawqa/protocols/OFR02-150/index. html

Patrick Center for Environmental Research, 1988, Diatom cleaning by nitric acid digestion: The Academy of Natural Sciences of Philadelphia, Protocol No. P-13-02.

Porter, S.D., 2008, Algal attributes-an autoecological classification of algal taxa collected by the National WaterQuality Assessment Program: U.S. Geological Survey Data Series 329, available online at http://pubs.usgs.gov/ds/ ds $329 \%$.

Taylor, W.D., Losee, R.F., Torobin, Marcia, Izaguirre, George, Sass, Debra, Khiari, Djanette, and Atasi, Khalil, 2006, Early warning and management of surface water taste-andodor events: American Water Works Association Research Foundation Report 91102F, 268 p.

U.S. Geological Survey, 2006, Collection of water samples (ver. 2.0): U.S. Geological Survey Techniques of WaterResources Investigations, book 9, chap. A4, accessed January 22, 2008, at http://pubs.water.usgs.gov/twri9A

U.S. Geological Survey, 2007, Water resources data for South Dakota, water year 2007: U.S. Geological Survey Water Data Reports: available on web, accessed February 18, 2008, at http://waterdata.usgs.gov/sd/nwis/sw/.

Williamson, Joyce E., and Carter, Janet M., 2001, Waterquality characteristics in the Black Hills area, South Dakota: U.S. Geological Survey Water-Resources Investigations Report 01-4194, 196 p., accessed May 27, 2008, at http://pubs.usgs.gov/wri/wri014194/. 
Zimmerman, L.R., Ziegler, A.C., and Thurman, E.M., 2002, Method of analysis and quality-assurance practices by U.S. Geological Survey Organic Geochemistry Research Group - determination of geosmin and methylisoborneol in water using solid-phase microextraction and gas chromatography/mass spectrometry: U.S. Geological Survey Open-File Report 02-337, 12 p., accessed May 27, 2008, at

http://ks.water.usgs.gov/Kansas/pubs/abstracts/ofr.02-337.html 



\section{Appendix. Algal Data for Rapid Creek and Canyon Lake}

Algal data were compiled and organized into three Excel spreadsheets (files) that each contain separate worksheets of results for each sampling site and an information worksheet. Each spreadsheet also contains a "Dominants" worksheet that summarizes the dominant algal taxa at each site. The information worksheets ("INFO") contain descriptions of the headings used in the worksheets. The file links and organizational structure are described in table 8 .

Phytoplankton concentration results (Phytoplankton.xls) are reported in units of cubic micrometers per liter of water column sample $\left(\mu \mathrm{m}^{3} / \mathrm{L}\right)$. Quantitative periphyton results (Quantitative.Periphyton.xls) are divided into two major sections on each result worksheet: "combined soft algae and generic diatom quantification" and "diatom classification and quantification." The first section reports biovolume concentrations for each algal division in units of cubic micrometers per milliliter $\left(\mu \mathrm{m}^{3} / \mathrm{mL}\right)$. This concentration also was normalized to the stream area from which the sample was collected. The normalized concentration is reported in units of cubic micrometers per square centimeter $\left(\mu \mathrm{m}^{3} / \mathrm{cm}^{2}\right)$. The second section provides a detailed community composition of diatoms (algal division Bacillariophyta; as described in the "Laboratory Methods" section of this report). These results are reported in units of cubic micrometers $\left(\mu \mathrm{m}^{3}\right)$ observed in the subsample, and were not normalized to either the sample volume or the stream area. Dividing each genus by the total biovolume observed in the diatom subsample yields the relative abundance of that particular genus. Qualitative periphyton results (Qualitative.Periphyton.xls) display the cell density of each genus identified in units of cells per liter of sample (cells/L). The total sample volume of each qualitative sample was arbitrary and the collection area was not measured, so these results cannot be normalized to a sample volume or stream area. 
Table 8. List of spreadsheets and their links that contain algal data.

[CL, Canyon Lake; RET, retention]

\begin{tabular}{|c|c|c|}
\hline Spreadsheet name/link & File description & Worksheets included \\
\hline Phytoplankton.xls & $\begin{array}{l}\text { Phytoplankton biovolume classified and enumerated quantitatively'. Each site } \\
\text { has a separate worksheet. The worksheet "Dominants" contains a summary } \\
\text { of the dominant algal taxa at each site. }\end{array}$ & $\begin{array}{l}\text { (1) INFO } \\
\text { (2) Dominants } \\
\text { (3) } 06413720 \\
\text { (4) } 06413200 \\
\text { (5) CL RET POND } \\
\text { (6) CL SOUTH } \\
\text { (7) CL NORTH } \\
\text { (8) CL DAM } \\
\text { (9) } 06412000\end{array}$ \\
\hline Quantitative.Periphyton.xls & $\begin{array}{l}\text { Periphyton biovolume classified and enumerated quantitatively. Each site has } \\
\text { a separate worksheet; both sample dates (May and September) are included } \\
\text { in the same worksheet if sampled twice. Each result worksheet contains two } \\
\text { sections: the first considers all diatoms generically, and the second provides } \\
\text { a diatom community composition based on biovolume of a subsample. The } \\
\text { worksheet "Dominants" contains a summary of the algal taxa with the high- } \\
\text { est relative biovolume abundance at each site. }\end{array}$ & $\begin{array}{l}\text { (1) INFO } \\
\text { (2) Dominants } \\
\text { (3) } 06413700 \\
\text { (4) } 06413570 \\
\text { (5) } 06413200 \\
\text { (6) } 06412900 \\
\text { (7) } 440321103181101 \\
\text { (8) } 06412000 \\
\text { (9) } 06411500\end{array}$ \\
\hline Qualitative.Periphyton.xls & $\begin{array}{l}\text { Periphyton cell density classified qualitatively }{ }^{2} \text {. Each site has a separate } \\
\text { worksheet; both sample dates (May and September) are included in the same } \\
\text { worksheet if sampled twice. The worksheet "Dominants" contains a sum- } \\
\text { mary of the dominant algal taxa at each site. }\end{array}$ & $\begin{array}{l}\text { (1) INFO } \\
\text { (2) Dominants } \\
\text { (3) CL JETTY } \\
\text { (4) PACTOLA RET POND } \\
\text { (5) CL NORTH } \\
\text { (6) CL DAM } \\
\text { (7) CL NORTH SHORE } \\
\text { (8) CL VEGETATION }\end{array}$ \\
\hline
\end{tabular}

${ }^{1}$ Quantitative data contains algal cell density, biovolume density, and relative abundance of organisms.

${ }^{2}$ Qualitative data can be used only to determine the presence or absence of organisms. 
Publishing support provided by:

Helena Publishing Service Center

For more information concerning this publication, contact: Director, USGS South Dakota Water Science Center 1608 Mt. View Rd.

Rapid City, SD 57702

(605) 394-3200

Or visit the South Dakota Water Science Center Web site at: http://sd.water.usgs.gov 


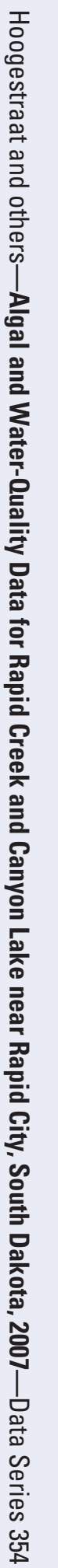

(3) Printed on recycled paper 